\title{
Explicit or Implicit Instruction of Metadiscourse Markers and Writing Skill Improvement
}

\author{
Ahmad Yaghoubi (Corresponding author) \\ ELT Department, Islamic Azad University, Roudehen Branch \\ PO Box 189, Roudehen, Iran \\ Tel: 00982176501709 E-mail: ayaghoobi@riau.ac.ir \\ Somayeh Ardestani \\ ELT Department, Islamic Azad University, Roudehen Branch \\ PO Box 189, Roudehen, Iran \\ Tel: 00989307378994 E-mail: somaiehardestanai@yahoo.com
}

Received: 17-01-2014

doi:10.7575/aiac.ijalel.v.3n.4p.14
Accepted: 23-02-2014

Published: 01-07-2014

URL: http://dx.doi.org/10.7575/aiac.ijalel.v.3n.4p.14

\begin{abstract}
The current study is an attempt to investigate the explicit or the implicit instruction of metadiscourse markers and the writing skill improvement. The participants of the study $(N=90)$ were female Iranian students at Kish Institute of Science and Technology. Two experimental groups were defined in this study: experimental group "A" which received the explicit instruction of metadiscourse markers and experimental group "B" which were taught implicitly based on Hyland's (2005) classification of metadiscourse markers. Two instruments were employed in the study: a pretest and a posttest. To elicit the pertinent data, the participants were given a pretest of writing ability to investigate if the learners had knowledge regarding the correct application of metadiscourse markers in their writing. After 8-session treatment, a posttest was administered to compare the participants' performance in use of matediscourse markers. The findings of the present study indicated that there was a significant difference in the participants' pretest and posttest writing scores with regard to the application of metadiscourse markers. The findings revealed that metadiscourse instruction had a positive effect on the learners' writing. In addition, the results showed that both the explicit and the implicit instruction of metadiscourse markers significantly improved participants' writing ability.
\end{abstract}

Keywords: Explicit instruction, Implicit instruction, Metadiscourse markers, Writing skill

\section{Introduction}

Writing, among language skills, has a special stand due to the literariness which comes with it. However, mastering it is not an easy task. Writing is not only mastering vocabulary and syntactic structure of the language or the mechanical manipulation of form but also it is like an art that needs instruction and practice in techniques in order to write effectively. Writing even in one's native language is not simply a matter of writing things down, and it is more than a mere transcription of speech. Such being the case, the use of rhetorical devises which are known as metadiscourse markers are considered as one of the significant features of writing.

Hyland (2004) argues that linguists are changing their point of view from ideational dimension of texts and speech to their interpersonal function to cope with their addresses' needs and expectations. Given this view, not only authors and speakers tend to create a text to transfer some information, but they also want to make their information more acceptable and understandable by encouraging their intended reader or listener to follow along.

Discourse is the social means of conveying broad historical meanings, and it is recognized by the social situations. (Henry \& Tator, 2002, p. 25). In other words, discourse is a general term for samples of language use (i.e. language that has been produced as the result of an act of complication). There are two levels in discourse. The propositional content is concerned with the initial level and the subsequent level of the discourse is about the act of discoursing called metadiscourse (Crismore, 1989). Metadiscourse is defined as "linguistic material in texts, written or spoken, which does not add anything to the propositional content but that is intended to help the listener or reader organize, interpret and evaluate the information given"(Crismore, Markkanen, \& Steffensen, 1993, p. 40). Metadiscourse is the level of discourse that adds another proposition to the propositional subject matter (Crismore, 1985).

The literature of many writing researches reports on the importance and the benefits of metadiscourse markers in L2 written products, and many researchers have focused on investigating various aspects of metadiscourse markers in learners' writing (Chen, 2006; Dastjerdi \& Shirzad, 2010; Fung, 2011; Martinez, 2004; Rezvani, Abdullah \& Baki, 2012).

Metadiscourse is viewed as a new approach which refers to how authors present themselves into a text and communicate with the intended addressees. Therefore, it plays a significant role in arranging the discourse, engaging the 
reader and addressing the communicative intentions (Fuertes-Olivera, Velasco-sacristan, Arribas-Bano, \& SamaniegoFernandez, 2001). Recently, the researchers have shown great interest in concept of metadiscourse and have discussed different aspects of it. Metadiscourse is known as an effective way of dramatic improvement in writing. In addition, it is a means of making textbooks more considerate (Cheng \& Steffensen, 1996; Crismore, 1984). Metadiscourse embodies the idea of communication for exchanging information, goods or services (Hyland, 2005). Moreover, it embraces a wide range of issues such as personalities, attitudes, belief, and assumptions of people who are interacting. Therefore, these interactions are articulated and constructed by means of metadiscourse (Hyland, 2005).

Metadiscourse helps readers understand the message in a way that is intended by its author. Hyland (1998) states that "based on a view of writing as a social and communicative engagement between writer and reader, metadiscourse focuses our attention on the ways writers project themselves into their work to signal their communicative intentions" (p. 437).

\subsection{Statement of the Problem}

Although previous studies have provided exhaustive effects on the writing skill, it seems that the EFL field is in need of further studies investigating this issue more deeply. It is obvious that effective and comprehensible writing should have coherence. Besides, it should have cohesion, in which cohesive devices are used to make the text meaningful. They are used to create connectivity of the text and link various parts of sentences as well as different sentences together. Furthermore, metadiscourse contains cohesion, grammar, and the consideration of the audience. Metadiscourse embodies the idea that communication is more of exchanging information, facts, goods, or services. It also includes personalities, attitudes and assumptions of people who are interacting (Hyland, 2005).

Many aspects of metadiscourse markers deserve to be explored and there is a huge gap for metadiscourse marker studies in the educational system of Iran. The current study regarded learners' writing from pragmatic perspective, which focused on the application of metadiscourse as a significant interactive feature.

\subsection{Significance of the Study}

Considering the importance of writing skill and its aspects in the educational field, it is observable that this skill can have a profound effect on different aspects of educational curriculum: in planning the course, organizing the objectives, preparing materials, teaching phases, syllabus design, assessing, and evaluating. That is why the present study has investigated the issues of metadiscourse markers and its effect on the explicit or the implicit instruction in Iranian EFL learners' writing skill.

In addition, metadiscourse is known as an effective technique for improving writing and a way to render textbooks to more considerate and reader friendly materials (Cheng \& Steffensen, 1996; Crismore, 1984; Hyland, 1998). Therefore, Iranian EFL practitioners can benefit the result of this study by implementing them in their written communicative activities, which become more effective by using metadiscourse markers.

Moreover, the current study investigated whether the implicit or the explicit instruction of metadiscourse markers leads to improvement of wring skill. It can shed more light on how to treat writing in classrooms. In addition, the present study is important as it may contribute to the continuing discussion regarding the explicit or the implicit instruction of metadiscourse markers in language learning with specific reference to Iranian foreign language learners.

The present study looked into the effect of the explicit or the implicit instruction of metadiscourse markers on the participants' writing and investigated which method of instruction is more beneficial and effective. It is hoped that the results of the present study cast some light on this issue and pave the way for a better teaching of writing.

\subsection{The Review of Literature}

The term Metadiscourse was "coined by Zellig Harris in 1959 to offer a way of understanding language in use, representing a writer's or speaker's attempts to guide a receiver's perception of a text" (Hyland, 2005, p. 3). The notion has been further developed by scholars, such as Vande Kopple (1985) and Crismore (1989). They have attempted to gather an extent of discoursal features, such as hedges, connectives, and different types of content editorial to show how authors and speakers encroach into their unfolding content to affect their questioner's gathering of it. Schiffrin (1980) asserts that metadiscourse refers to the author's linguistic manifestation in a text to "bracket the discourse organization and the expressive implications of what is being said" (p. 231). Additionally, Vande Kopple (1985) states that metadiscourse is essentially 'text about the text' and it is the linguistic material of text that does not add propositional content, but rather signals the presence of the author as s/he helps the reader "organize, classify, interpret, evaluate, and react to such material" (p. 83). Similarly, Williams (2007) defines it as "the language that writers use to refer not to the substance of their ideas but to themselves, their readers, or their writings" (p. 65). Therefore, it is observed that there are various views on the functions of metadiscourse markers.

The focus of the present study is on one of the most current taxonomies of metadiscourse markers proposed by Hyland. Hyland (2005) attempts to introduce some earlier classifications of metadiscourse and believes metadiscourse markers comprise of two main taxonomies - interactive and interactional. Interactive resources are "a consequence of the writer's assessment of the reader's assumed comprehension capacities, understandings of related texts, and need for interpretive guidance, as well as the relationship between the writer and reader" (Hyland, 2005, p. 50). Interactional resources "involve readers and open opportunities for them to contribute to the discourse by alerting them to the 
author's perspective towards both propositional information and readers themselves. They help control the level of personality in a text as writers acknowledge and connect to others" (Hyland, 2005, p. 52).

\subsection{Other Studies Done in the Same Field}

Dastjerdi and Shirzad (2010) investigated the effect of explicit instruction of metadiscourse markers on EFL learners' writing ability. Ninety-four university students divided into three levels of advanced, intermediate, and elementary through the administration of a Michigan Proficiency Test. They found that explicit instruction of metadiscourse makers significantly increased EFL learners' writing ability at three levels. Elementary learners improved significantly after explicit instruction of metadiscourse markers. Their findings revealed that intermediate learners had the highest improvement in their writing ability. Advanced learners showed the least improvement after the explicit instruction of metadiscourse markers. In other words, intermediate EFL learners showed more dramatic improvement in their writings than the other groups.

In a very recent study, Taghizade and Tajabadi (2013) investigated the effect of instruction of metadiscourse markers on writing performance of the EFL learners. The participants were thirty-two male Iranian students at Sharif University of Technology and Amirkabir University of Technology. They received a four week instruction concerning the Hyland's (2000) classification of metadiscourse. Two instruments, a pretest and a posttest were used. The results of paired samples $t$ test indicated a significant difference in learners' writing scores. The findings of their study revealed that the metadiscourse markers instruction was beneficial and led to a better writing performance of the EFL learners.

\subsection{Research Questions}

Specifically, the present study is aimed at addressing the following research questions:

Q1. Does the explicit instruction of metadiscourse markers have any significant effect on the witting performance of the EFL learners?

Q2. Does the implicit instruction of metadiscourse markers have any significant effect on the writing performance of the EFL learners?

Q3. Is there any significant difference in the performance of those who receive the explicit instruction on metadiscourse markers and those who receive the implicit instruction?

\section{Methods}

\subsection{Participants}

The participants of the present study were ninety female advanced learners at Kish Institute of Science and Technology. The participants were divided into one control group $(N=30)$ and two experimental groups $(N=60)$. One of the experimental groups received the explicit instruction on metadiscourse markers and the other one was exposed to the implicit instruction.

\subsection{Instruments}

Three instruments were used in the current study. The first instrument, a TOEFL proficiency test, was administered to ninety L2 learners to determine the participants' level of homogeneity in terms of their general language proficiency. The next instrument, a pretest, was administered to the participants to determine their initial knowledge and their command in the use of metadiscourse markers. Finally, a posttest was administered to compare the performance of learners in control group with those in experimental groups (i.e., those receiving the explicit and the implicit instruction of metadiscourse markers).

\subsection{Procedure}

Initially, the pretest of writing was administered to the control and the experimental groups. Learners were asked to write a composition of 300 words on the topic entitled "The negative effects that tourist can have upon an area. Give reasons to support your answer". The purpose of administering the pretest was to investigate if the learners had knowledge regarding the correct application of metadiscourse markers in their writing.

Two experimental groups were defined in this study. Experimental group A was exposed to the explicit instruction of metadiscourse markers during eight successive sessions. Based on the Hyland metadiscourse markers framework (2005), a handout including a list of definitions and examples of interactive and interactional metadiscourse markers was given to the learners (Appendix). The instructors provided the learners with the definitions and examples of the above categories. After having been exposed to instruction on each metadiscourse marker, the learners were required to write down sentences using them. Furthermore, the participants were given a cloze test with deleted metadiscourse markers and were asked to employ the appropriate markers, and as the homework assignment, they were required to complete another cloze test back home with the appropriate metadiscourse markers.

Learners in the experimental group B were exposed to the implicit instruction on metadiscourse markers for eight successive sessions. In the first session, they were given a reading text consisting of different metadiscourse markers, while the instructor read it for them. All metadiscourse markers were bold and underlined. Then, they were given another reading text and were asked to find and underline the metadiscourse markers in the text. In addition, they were given a passage with deleted metadiscourse markers and were asked to employ the appropriate markers in it. During the treatment sessions, they were repeatedly exposed to various reading texts read aloud by the instructor. In addition, as the homework assignment, they were required to complete cloze tests with the appropriate metadiscourse markers. 
Finally, as the posttest, a 300 word composition writing test was administered to all the three groups to compare the participants' performance on the use of metadiscourse markers. The participants were quested to write an essay on a topic entitled "Examinations exert a harmful influence on education. Do you agree? Give reasons to support your answer". The rationale for utilizing two different tests was avoiding the problem of interfering variable due to topics for the pretest and the posttest. Moreover, having two topics for the pretest and the posttest does not have any negative impact on the findings due to the fact that in the scoring procedure, the focus was merely on the application of the metadiscourse markers. It means that the correct application of grammar and vocabulary and more were not considered. Then, the participants' scores on the pretest and the posttest were compared to determine their level of achievement and improvement in writing performance. Each metadiscourse marker had the value of 2 marks in the scoring procedure. The pretest and the posttest were scored out of 20 marks.

Because the scoring of participants' writing was subjective, two independent raters scored the participants' writings to increase the validity. The two raters were two teachers who had several years of experience in teaching different levels of English courses at Kish Institute of Science and Technology in Tehran. They focused on the number and the appropriate use of metadiscourse markers, the extent of cohesiveness that students made between sentences in their writing, and the clear and close relationship among ideas.

\subsection{Design of the Study}

The present study used a quasi-experimental design. According to Best and Kahn (2006) when "random assignment to experimental and control treatments has not been applied, the equivalence of the groups is not assured and the research will have Quasi-experimental design" (p. 183).

\subsection{Data Analysis}

In order to evaluate the effect of the explicit or the implicit instruction of metadiscourse markers on writing skill improvement, the scores from the posttest (treatment test) were analyzed. A One-way ANOVA was used to assess the impact of the explicit and the implicit instruction of metadiscourse markers on the writing skill improvement. Since the researcher had three experimental groups (more than two groups), analysis of variance (ANOVA) was used. According to Best and Kahn (2006), "ANOVA is an effective way to determine whether the means of more than two samples are too different to attribute to sampling error" or not (p. 423). Since the researcher will not add any other variable, a OneWay ANOVA is used. According to Best and Kahn (2006), "in single classification, or one-way analysis of variance, the relationship between one independent and one dependent variable is examined" (p. 423).

Furthermore, a One-Way ANOVA was used to investigate whether the explicit instruction of metadiscourse markers was effective or the implicit instruction. It compares the changes and improvement of different groups (experimental groups) after the application of the explicit or the implicit treatment.

\section{Results}

In order to provide an answer to the research questions, several statistical analyses were performed, the results of which are reported and discussed below.

\subsection{Language Proficiency Test}

The first step to do the current research was to pilot the proficiency test. For this, at the beginning of the study, a test of TOEFL was administered to 30 students whose language proficiency level was similar to the participants of this study. This test consisted of 90 multiple-choice items with 40 items on structure and written expressions, and 50 items on reading comprehension. Then a process of item analysis was carried out for the test in order to identify and discard the poor items. The item facility and item discrimination of each item were calculated. Items with facility indices below .30 and beyond .70 and discrimination values below .40 were discarded. After analyzing the items through Item Facility and Item Discrimination, 5 structure questions and 10 reading questions were recognized as malfunctioning and removed. Afterward, 35 structure questions and 40 reading questions were set for the homogenizing test.

Table 1. Descriptive statistics of the language proficiency test piloting

\begin{tabular}{llllll}
\hline & $\mathrm{N}$ & Min. & Max. & Mean & SD \\
\hline Total & 30 & 19 & 86 & 50.13 & 20.82 \\
\hline
\end{tabular}

Table 1 provides the descriptive statistics of the language proficiency test in the piloting phase. Before administrating the TOEFL to the samples ( 90 participants), the reliability of each section was estimated through Cronbach's alpha in order to check the extent to which we were able to capture variance which is truly due to the participants' performance. Farhadi, Jafarpoor and Birjandi (1994) claim the reliability beyond .60 is quiet acceptable. The reliability of the structure section was .92 , the reading section's reliability was .93 , and the reliability of the Language Proficiency Test was .96 , which is considered reliable. 
Table 2. Reliability statistics of the language proficiency test

\begin{tabular}{ccc}
\hline & Cronbach's alpha & N of Items \\
\hline TOEFL & .96 & 75 \\
\hline
\end{tabular}

Table 2 provides the reliability of the language proficiency test (.96) in the piloting phase. In addition, to have an estimate of construct validity a differential-group study was performed. The developed test was administered to a group of 30 students whose language proficiency level was higher than the participants of the present study were.

Table 3. descriptive statics to compare the two groups

\begin{tabular}{lllll} 
Groups & $\mathrm{N}$ & Mean & Std. Deviation & Std. Error Mean \\
\hline 1 & 30 & 67.73 & 2.970 & .5423 \\
2 & 30 & 70.63 & 2.918 & .5327 \\
\hline
\end{tabular}

The above Table shows the results gained by this group of students. As Table 3 shows, there are almost three scores differences between the mean of the two groups. To ascertain the significance of this difference and consequently the construct validity of the test an independent sample $t$ test was run between the mean scores of the two groups.

Table 4. $t$ test to compare the two groups

\begin{tabular}{|c|c|c|c|c|c|c|c|c|c|}
\hline & \multicolumn{9}{|c|}{$\begin{array}{l}\text { Levene's Test } t \text { test for } \\
\text { for Equality of Equality } \\
\text { Variances }\end{array}$} \\
\hline & \multirow[b]{2}{*}{$\mathrm{F}$} & \multirow[b]{2}{*}{ Sig. } & \multirow[b]{2}{*}{$\mathrm{T}$} & \multirow[b]{2}{*}{ Df } & \multirow[b]{2}{*}{$\begin{array}{l}\text { Sig.(2- } \\
\text { tailed) }\end{array}$} & \multirow[b]{2}{*}{$\begin{array}{l}\text { Mean } \\
\text { Difference }\end{array}$} & \multirow[b]{2}{*}{$\begin{array}{l}\text { Std. Error } \\
\text { Difference }\end{array}$} & \multicolumn{2}{|c|}{$\begin{array}{l}95 \% \text { Confidence Interva } \\
\text { of the Difference }\end{array}$} \\
\hline & & & & & & & & Lower & Upper \\
\hline $\begin{array}{l}\text { Equal } \\
\text { variances } \\
\text { assumed }\end{array}$ & .040 & .842 & -3.815 & 58 & .000 & -2.90000 & .76024 & -4.42179 & -1.37821 \\
\hline $\begin{array}{l}\text { Equal } \\
\text { variances not } \\
\text { assumed }\end{array}$ & & & -3.815 & 57.982 & .000 & -2.90000 & .76024 & -4.42180 & -1.37820 \\
\hline
\end{tabular}

As Table 4 shows, the observed mean difference is significant at $\mathrm{p}=.05$ level of significance with the amount of $t=$ 3.81. This means that the two groups had significantly different performances on the newly developed test. This in turn confirms the construct validity of the newly developed test since we have been able to show that groups of students who were in higher proficiency level were significantly different from a group of students who did not have this construct.

The researcher felt safe in employing the above test for the selection of the participants of the study. The language proficiency test was administered to 90 advanced level students of three intact classes. They were randomly assigned into three groups, as one control and two experimental groups so that all the participants had equal chance to be in either the control group or experimental ones. Each group consisted of 30 participants.

Table 5. Descriptive statistics of the language proficiency test of the three groups

\begin{tabular}{llllll} 
& $\mathrm{N}$ & Mean & SD & Skewness & \\
\cline { 2 - 5 } & & & & Statistic & Std. Error \\
Control & 30 & 67.50 & 2.64 & .203 & .427 \\
EXA & 30 & 67.73 & 2.97 & .219 & .427 \\
EXB & 30 & 67.83 & 2.65 & .430 & .427 \\
\hline
\end{tabular}


The descriptive statistics of the language proficiency test of the three groups appear in Table 5. Dividing the statistic of skewness by its standard error, the researcher found that the assumption of normality was observed in the distribution of the scores of the three groups $(.47, .51$, and 1.00 for the control, EXA, and EXB groups respectively, all falling within the range of -1.96 and +1.96$)$.

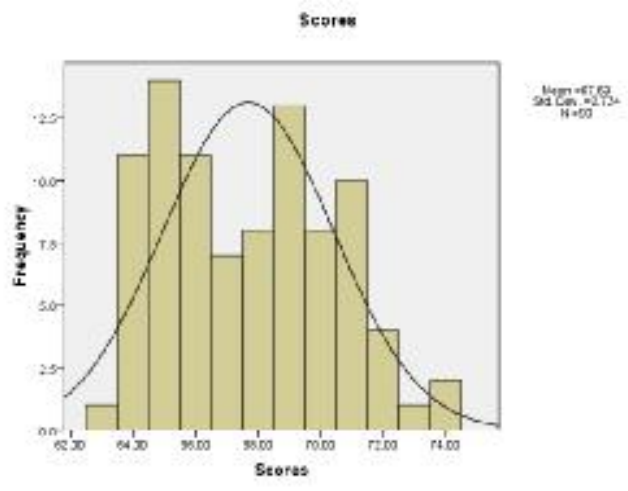

Figure 1. Histogram of the Language Proficiency Test

Figure 1. displays the normality of the language proficiency test.

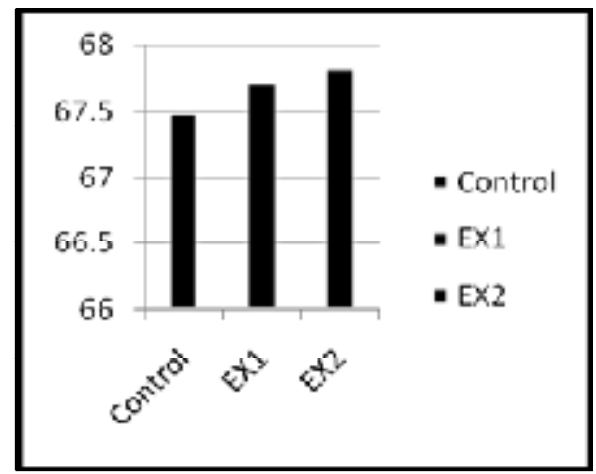

Figure 2. The Mean Differences of the Three Groups on the Language Proficiency Test

Figure 2 shows the mean differences of the three groups on the language proficiency test. It should be noted that the three groups were homogenous in terms of their variances in the language proficiency test.

Table 6. Test of homogeneity of variance

\begin{tabular}{clll}
\hline Levene Statistic & $\mathrm{df1}$ & $\mathrm{df1}$ & $\mathrm{df1}$ \\
\hline .564 & 2 & 87 & .571 \\
\hline
\end{tabular}

As Table 6 shows, he Levene's F of .56 has a probability of .57. Since the probability associated with the Levene F is higher than the .05 level of significance, it can be concluded that the three groups enjoyed homogenous variances.

\subsection{ANOVA for the Writing Pretest Mean Score}

In order to determine the homogeneity of the participants regarding their writing skill, the researcher ran an ANOVA. It should be noted that the three groups were homogenous in terms of their variances in the pretest.

Table 7. Test of homogeneity of variances pretest

\begin{tabular}{cccc}
\hline Levene Statistic & df1 & df2 & Sig. \\
\hline .36 & 2 & 87 & .69 \\
\hline
\end{tabular}

The Levebne's F of .36 has a probability of .69 (Table 7). Since the probability associated with the Levene F is higher than the .05 level of the significance, it can be concluded that the three groups enjoyed homogenous variances. 
Table 8. One-way ANOVA for the pretest

\begin{tabular}{cccccc}
\hline & Sum of Squares & df & Mean Square & F & Sig. \\
\hline Between Groups & 9.800 & 2 & 4.900 & .717 & .491 \\
Within Groups & 594.300 & 87 & 6.831 & & \\
Total & 604.100 & 89 & & & \\
\hline
\end{tabular}

The probability associated with the F-observed value (.717) was higher than the significant level of .05 (Table 8). Therefore, it was safely concluded that the three groups belonged to the same population in terms of writing before the treatment.

\subsection{ANOVA for the Writing Posttest Mean Scores}

In order to compare the means of the three groups on the writing posttest, an ANOVA was run again. It should also be noted that the three groups were homogenous in terms of their variances in the posttest.

Table 9. Test of homogeneity of variances posttest

\begin{tabular}{cccc}
\hline Levene Statistic & df1 & df2 & Sig. \\
\hline .75 & 2 & 87 & .47 \\
\hline
\end{tabular}

The Levene's F of .75 has a probability of .47 (Table 9). Since the probability associated with the Levene F is higher than the .05 level of significance, it can be concluded that the three groups enjoyed homogenous variances.

Table10. One-way ANOVA for the posttest

\begin{tabular}{|c|c|c|c|c|c|}
\hline & Sum of Squares & Df & Mean Square & $\mathrm{F}$ & Sig. \\
\hline Between Groups & 493.95 & 2 & 246.97 & 20.68 & .000 \\
\hline Within Groups & 491.86 & 87 & 5.654 & & \\
\hline Total & 985.82 & 89 & & & \\
\hline
\end{tabular}

In order to answer the third research question, an independent $t$ test should have been run to find any significant difference in the performance of those who received the explicit instruction on matediscourse markers and those who received the implicit instruction.

Table 11. Independent samples test

\begin{tabular}{|c|c|c|c|c|c|c|c|c|c|c|}
\hline & & \multicolumn{4}{|c|}{$\begin{array}{c}\text { Levene's Test for } \\
\text { Equality of } \\
\text { Variances }\end{array}$} & \multicolumn{5}{|c|}{$t$ test for Equality of Means } \\
\hline & & \multirow[b]{2}{*}{$\mathrm{F}$} & \multirow[b]{2}{*}{ Sig. } & \multirow[b]{2}{*}{$\mathrm{T}$} & \multirow[b]{2}{*}{ df } & \multirow{2}{*}{$\begin{array}{l}\text { Sig.(2- } \\
\text { tailed) }\end{array}$} & \multirow{2}{*}{$\begin{array}{l}\text { Mean } \\
\text { Difference }\end{array}$} & \multirow{2}{*}{$\begin{array}{l}\text { Std. Error } \\
\text { e Difference }\end{array}$} & \multicolumn{2}{|c|}{$\begin{array}{l}95 \% \\
\text { Confidence } \\
\text { Interval of the } \\
\text { Difference }\end{array}$} \\
\hline & & & & & & & & & Lower & Upper \\
\hline $\begin{array}{l}\text { Posttest } \\
\text { Scores }\end{array}$ & $\begin{array}{l}\text { Equal } \\
\text { variances } \\
\text { assumed }\end{array}$ & .542 & .464 & .350 & 58 & .728 & .200 & .572 & -.944 & 1.344 \\
\hline & $\begin{array}{c}\text { Equal } \\
\text { variances } \\
\text { not assumed }\end{array}$ & & & .350 & 57.655 & .728 & .200 & .572 & -.945 & 1.345 \\
\hline
\end{tabular}


As indicated in Table 11, it can be concluded that from $t(58)=0.35, p=.72$ that there was no significant difference between the mean scores of the two experimental groups at the posttest.

\section{Discussion}

The main concern of the present study was to investigate the effect of the explicit or the implicit instruction of metadiscourse markers on the writing skill improvement of Iranian L2 learners. Tobridge the results and the hypotheses of the current study, this section is allotted to the verification of null hypotheses.

\subsection{The First and the Second Null Hypotheses}

The first null hypothesis states that the explicit instruction of metadiscourse markers does not have any significant effect on the writing performance of the EFL learners. The participants of the study took a pretest and posttest on the writing ability. Additionally, the second hypothesis states that the implicit instruction of metadiscourse markers does not have any significant effect on the writing performance of the EFL learners. Regarding these hypotheses, a One-way ANOVA was employed to compare the pretest and the posttest results. The Levene's F of .75, as displayed in Table 10, has a probability of .47. The probability associated with the F-observed value (.00) was lower than the significant level of .05 . Therefore, it was concluded that both the explicit and the implicit instructions of matediscourse markers have significant effects on the writing performance of the EFL learners. So the first and second null hypotheses were rejected.

\subsection{The Third Null Hypothesis}

For analyzing significant difference in the performance of those who receive the explicit instruction on metadiscourse markers and those who receive the implicit instruction, an independent samples $t$ test was run. The probability associated with the t-observed value $(t(58)=.35, \mathrm{p}=.72)$, as displayed in Table 11, was higher than the significant level of .05. It can be concluded that from $t$ (58) that there was no significant difference between the mean scores of the two experimental groups at the posttest. On the whole, it was concluded that the explicit and the implicit instructions of metadiscourse markers were the key elements in the superiority of the two experimental groups over the control group in terms of writing. However, it was concluded that there is no significant difference in the performance of those who received the explicit instruction on matediscourse markers and those who received the implicit instruction. Therefore, the third null hypothesis was failed to be rejected. In other words, it became apparent that the explicit instruction of metadiscourse markers did not lead to higher writing skill improvement than the implicit instruction.

The findings of the study revealed that the metadiscourse instruction was effective in improving the learners' writing. Furthermore, the results showed that both the explicit and the implicit instruction of metadiscourse markers significantly improve participants' writing ability. It is hoped that the findings of the study make language teachers aware of the significance of metadiscourse and assist learners to improve their writing tasks by applying these linguistic elements.

\section{Acknowledgements}

I would like to express my deepest gratitude to all those who gave me the possibility to complete the current paper. I am also deeply indebted to my advisor Dr. Ahmad Yaghoubi whose help, stimulating suggestions and encouragement helped me during all of the phases of this paper. I am thankful to Dr. Hamidreza Fatemipour, who provided valuable feedback and insightful suggestions on this paper. Without a well-designed plan, generous help, and meticulous review of these two persons, the successful completion of this paper would have been impossible.

\section{References}

Best, J. W., \& Kahn, J. V. (2006). Research in education (3rd ed). United States of America: Pearson Education Inc.

Chen Ch. W. (2006). The use of conjunctive adverbials in the academic papers of advanced Taiwanese EFL learners. International Journal of Corpus Linguistics, 11 (1), 113-130.

Cheng, X., \& Steffensen, M. (1996). Metadiscourse: A technique in improving students writing. Research in the Teaching of English. 30 (2), 149-81.

Crismore, A. (1984). The rhetoric of social studies textbooks: Metadiscourse. Journal of Curriculum Studies, 16 (3), 279-296.

Crismore, A. (1985). Metadiscourse in social studies texts. Technical report, 366, 155-179

Crismore, A. (1989). Talking with readers: Metadiscourse as rhetorical act. New York: Peter Lang.

Crismore, A., Msarkkanen R., \& Steffensen, M. (1993). Metadiscourse in persuasive writing: A study of texts written by American and Finnish university students. Written Communication, 10, 39-71.

Dastjerdi, H. V., \& Shirzad, M. (2010). The impact of explicit instruction of metadiscourse markers on EFL learners' writing performance. The Journal of Teaching Language Skills, 2 (2), 155- 174.

Farhadi, H., Jafarpoor, A., \& Birjandi, P. (1994). Language skills testing: From theory to practice. Tehran, Iran: SAMT.

Fuertes-Olivera, P. A., Velasco-sacristan, M., Arribas-Bano, A., \& Samaniego-Fernandez, E. (2001). Persuasion and advertising English: Metadiscourse in slogans and headlines. Journal of Pragmatics, 33, 1291-1307. 
Fung, L. (2011). Discourse markers in the ESL classroom: A survey of teachers' attitudes. The Asian EFL Journal Quarterly, 13 (2), 199-248.

Henry, F. \& Tator ,C .(2000). Discourses of Domination: Racial bias in the Canadian English language press. London: University of Toronto Press.

Hyland, K. (1998). Persuasion and context: The pragmatics of academic metadiscourse. Journal of Pragmatics, 30, 437.

Hyland, K. (2000). Talking to students: Metadiscourse in introductory textbooks. English for Specific Purposes, 18, 326.

Hyland, K. (2004). Disciplinary discourses: Social interactions in academic writing. Longman: Pearson.

Hyland, K. (2005). Metadiscourse: Exploring interaction in writing. London: Continuum.

Martinez, A. C. L. (2004). Discourse markers in the expository writing of Spanish university students. IBERICA, 8, 6380.

Rezvani, S. A., Abdullah, A., \& Baki, R. (2012). Constructing an organized and coherent text: How discourse markers are viewed by Iranian post-graduate students? International Journal of Humanities and Social Science, 2 (9), 196-209.

Schiffrin, D. (1980). Meta-talk: Organisational and evaluative brackets in discourse. Sociological Inquiry: Language and Social Interaction, 50, 199-236.

Taghizade, M. \& Tajabadi, F. (2013). Metadiscourse in Essay Writing: An EFL Case. International Research Journal of Applied and Basic Sciences. 4 (7), 1658-1662.

Vande Kopple, W. J. (1985). Some exploratory discourse on metadiscourse. College Composition Communication, 1 (36), 82-93.

Williams, J. (2007). Style: Ten Lessons in Clarity and Grace, (9th ed). New York: Pearson-Longman.

\section{Appendix}

Hyland's model of metadiscourse markers (Hyland, 2005, pp. 50-53)

\begin{tabular}{|l|l|}
\hline \multicolumn{1}{|c|}{ Interactive Resources } & \\
\hline Transition Markers & $\begin{array}{l}\text { Addition; and; furthermore; moreover; by the way; } \\
\text { Comparison Marks: similarly; likewise; equally; in the } \\
\text { same way; correspondingly; in contrast; however; but; } \\
\text { on the contrary; on the other hand; } \\
\text { Consequence; thus; therefore; consequently; in } \\
\text { conclusion; admittedly; nevertheless; anyway, in any } \\
\text { case; of course }\end{array}$ \\
\hline Frame Markers & $\begin{array}{l}\text { to summarize; in sum; by way of introduction; I argue } \\
\text { here; my purpose is; the paper proposes; I hope to } \\
\text { persuade; there are several reasons } \\
\text { why; well right; now; let us return to }\end{array}$ \\
\hline Endophoric Marker & see Figure 2; refer to the next section; as noted; above \\
\hline Evidentials & $\begin{array}{l}\text { Date; name; to) cite X; (to) quote X: } \\
\text { according to X; cited; quoted }\end{array}$ \\
\hline Code Glosses & $\begin{array}{l}\text { this is called; in other words; that is; this can be defined } \\
\text { as; for example }\end{array}$ \\
\hline Interactional Resources & $\begin{array}{l}\text { likely; may; maybe; might; perhaps; } \\
\text { possible; possibly; probable; probably } \\
\text { uncertain; uncertainly; fairly; almost, partly; unlikely }\end{array}$ \\
\hline Hedges & Certainly; demonstrate; really; totally, always \\
\hline Boosters & $\begin{array}{l}\text { agree, prefer; unfortunately; hopefully; } \\
\text { appropriate; logical; remarkable }\end{array}$ \\
\hline Attitude Markers & $\begin{array}{l}\text { I; we; me; my; our; mine; us; the author; } \\
\text { the author's; the writer; the writer's }\end{array}$ \\
\hline Self-mention & you; your; yourself; must; should; of course; obviously \\
\hline Engagement Markers & \\
\hline
\end{tabular}

